\title{
Malmquist Indices of Pre and Post-Deregulation Productivity, Efficiency and Technological Change in the Singaporean Banking Sector
}

\author{
Boon L. Lee* \\ School of Economics and Finance, Queensland University of Technology, Brisbane, Queensland, \\ Australia. \\ Andrew C. Worthington \\ Department of Accounting, Finance and Economics, Griffith University, Nathan, Queensland, \\ Australia.
}

Wai Ho Leong

Economics Division, Ministry of Trade and Industry, Singapore

\begin{abstract}
By the end of the 1990s, the Singaporean government had recognised the need to open up its banking sector so as to remain competitive in the global economy. The Monetary Authority of Singapore thus began deregulation of the banking sector in 1999 to strengthen the competitiveness of local banks relative to their foreign competitors through mergers. This paper employs a nonparametric Malmquist productivity index to provide measure of productivity, technological change and efficiency gains over the period 1995-2005. The findings reveal some total factor productivity growth associated with deregulation and scale efficiency improvement largely from mergers amongst the local banks.
\end{abstract}

Keywords: Efficiency, productivity; deregulation; Malmquist indices; banking

JEL classifications: G21, D24

\footnotetext{
* Corresponding author: School of Economics and Finance, Queensland University of Technology, GPO Box 2434, Brisbane, QLD 4001, Australia. Tel: +61 (0)7 3138 5389; Fax. +61 (0)7 3138 1500; email: bl.lee@qut.edu.au
} 


\section{Introduction}

Since the beginning of the 1980s, financial institutions in many parts of the world have undergone changes brought about by deregulation, globalisation, privatisation and the rapid pace of development in information technology. This phenomenon is very evident in countries such as Australia, Belgium, France, Germany, Italy, Japan, South Korea, the Netherlands, Norway, Spain, the United Kingdom and the United States. Similar developments are found in the Singaporean banking sector whereby recent regulatory changes have been spurred by the challenges of global competition. Singapore's central bank, the Monetary Authority of Singapore (MAS), recognized the need to deregulate its financial sector and open its domestic banking and insurance industries to foreign competition. This was undertaken not only to remain competitive in the global economy, but also to strengthen its banking system in terms of the quality of banking services and to maintain or increase market share. Both the Singaporean government and the MAS were well aware of the small stature of local banks by international standards and lags behind international banks “...in terms of technology, expertise, range and quality of service to customers” (MAS, 1999, p.1). Recent technological developments have led to banking services being no longer restricting to 'bricks and mortar' over-the-counter services with e-banking becoming more prevalent. This new approach to banking enables foreign banks to extensively reach out to domestic customers, which, in a matter of time, would further reduce and neutralise the advantages of an extensive branch network and implicit and explicit government protection (MAS, 1999). 
In 1997, MAS reviewed its regulatory policies and in 1999, launched the first phase of a five-year programme aimed at liberalising the banking sector in Singapore. The programme, essentially aimed at the development and upgrading of local banks, had three key features: (i) an increase in competition from giving access to foreign banks to enter the domestic market; (ii) strengthening the corporate governance of local banks and attracting leadership talent so as to reach a level of autonomy mature enough to make professional management decisions; and (iii) lifting the forty percent foreign shareholding limit. With the onset of deregulation, the role of MAS changed from regulation to supervision with the aim to “...monitor and differentiate among institutions by giving the stronger and well-managed ones more operational flexibility while maintaining stricter controls on the weaker ones” (MAS, 1998, p. 29).

The onus was now on banks to effectively govern themselves through the setting-up of Nominating Committees to offer appointments to key management positions. The five-year programme, which includes a package of new banking privileges and licences for foreign banks, opened up the domestic banking sector in terms of the issuing of full banking licenses, known as Qualifying Full Banks (QFBs), to foreign banks. The first phase of the programme saw four foreign banks being awarded QFB privileges in October 1999. These comprised ABNO Amro Bank MV, Banque Nationale de Paris, Citibank NA, and Standard Chartered Bank. In addition, an additional eight Qualifying Offshore Banks (QOBs) and eight wholesale bank licenses were granted in the first phase of the programme. ${ }^{1}$

\footnotetext{
${ }^{1}$ Wholesale banks are permitted to engage in the same range of banking services as QFBs, except for the acceptance of Singapore dollar fixed deposits of less than S\$250,000 per deposit from non-bank customers, and the payment of interest on Singapore dollar current accounts operated by resident
} 
The second phase of the programme launched in June 2001 saw MAS freeing up the wholesale bank market by awarding twenty wholesale bank licences over the following two years and the upgrading of existing QOBs and offshore banks to wholesale bank status. In December 2001, MAS awarded two QFBs and sixteen wholesale bank licences, of which eight were converted from QOBs. By May 2003, eight other wholesale bank licences were awarded. The second phase of the programme focused on the replacement of the restricted bank licenses with wholesale bank licenses thus allowing a wider range of banking activities to be conducted (hence the renaming of restricted banks to wholesale banks). This move restructured MASs' three-tiered banking license of Full, Restricted and Offshore banks, towards a more streamlined two-tiered licensing regime of Full and Wholesale banks. The upgrade of Qualifying Offshore Banks and Offshore Banks to Wholesale Banking status for the period 1998-2005 is evident in Table 1 with the rising number of Wholesale banks and the falling number of Offshore banks.

Revisions to the QFB licenses were also carried out in the second phase with an increase in the number of locations from ten to fifteen. Prior to revision of the QFB licenses, foreign banks were allowed up to ten locations, of which five could be branches. The new privileges attached to the QFB license now increased the limits of individuals. Offshore banks, besides having the same restrictions imposed on Wholesale banks, have slightly more restrictions on dealings with residents in terms of the acceptance of interest-bearing deposits from resident non-bank customers other than approved financial institutions. Further, the credit limit was limited to S\$300 million to non-bank customers who are Singapore residents. But with liberalisation, the QOB privileges were relaxed and allowed to have their lending limit raised to S\$1 billion, from the previous limit of S\$300 million. QOBs were also be allowed to accept S\$ funds from non-bank customers through swap transactions. 
foreign banks to fifteen locations, of which ten could be branches and the remainder as off-site automated teller machines (ATMs). In addition, QFBs could also provide debit services through Electronic Funds Transfer at Point of Sale (EFTPOS) networks, thus enhancing competition in retail banking through the permitted issue of debit cards to consumers.

As shown in Table 1, as of March 1999 there were 142 commercial banks, comprising 9 local banks, 22 full banks, 13 wholesale banks (previously termed restricted banks) and 98 offshore banks. By March 2006, there were 108 commercial banks, of which 5 were local banks, 24 were full banks, 35 were wholesale banks and 34 were offshore banks. The drop in the number of local banks was the result of mergers and acquisitions: namely, DBS acquired the Post Office Savings Bank (POSB) in 1998; Keppel and Tat Lee merged to become Keppel-Tatlee in 1998; the United Overseas Bank (UOB) and Overseas Union Bank (OUB) merged to become UOB in 2002, the Overseas Chinese Banking Corporation (OCBC) and Keppel-Tatlee Bank merged in 2002; and the Industrial \& Commercial Bank (ICB) Limited and UOB merged in August $2002^{2}$. The driving force behind the government's desire for the consolidation of the local banks was the issue of size. Then Deputy Prime-Minister Lee expressed the rationale as follows: “...the logic of Singapore’s position is inescapable. If we want strong banks, then they have to be big banks and if they are big banks, then we must have fewer banks. This is the reality in many small countries”3.

INSERT Table 1.

\footnotetext{
${ }^{2}$ Prior to merger, the Industrial \& Commercial Bank (ICB) was a subsidiary of UOB.

${ }^{3}$ Quote from article by Angela Tan, BG Lee: Singapore to Stay Open to Global Players, Business Times, June 3, 2001.
} 
Strangely enough in the midst of deregulation, Singapore's largest bank, the Development Bank of Singapore (DBS), was not completely privatised, and though publicly listed was still partly government-owned in terms of shareholdings ${ }^{4}$. Further, despite more foreign banks being granted QFB licenses, the privileges were still rather limited, even after the revisions in 2001. For instance, foreign QFBs are limited to sharing ATMs amongst themselves and are not permitted to access the local banks' ATM networks. Arguably, the most important reason for this quasi-market is national interest. MAS still has an important role in the form of supervision over the smaller banks. The strengthening of corporate governance to maintain a high prudential standard is vital to the survival of local banks in order to compete with foreign banks.

However, failure to effectively supervise can have dire consequences, as realised in the 1991-1993 banking crises in Norway and Sweden. Many banks suffered severely from substantial credit losses as a result of poor management and failure to appropriately evaluate the risk-levels. In addition, the financial system problems are associated with the deflation of real estate values (Bartholomew 1994; Ball 1994). The eventual outcome was government intervention through the issue of general guarantees and bailing out banks (Lindblom, 1994). In Norway, the two largest banks in Norway; Denorske Bank (DnB) and Christiania Bank og Kreditkasse (CBK), were nationalised. The government's long-term goal was to retain a substantial minority position (20-33.33\%) over these two banks. In Sweden, the measures were less drastic with government bailouts (Skandinaviska Enskilda Banken in Sweden).

\footnotetext{
${ }^{4}$ Temasek Holdings (Pte) Ltd, a company wholly owned by the Ministry for Finance Incorporated, is the investment arm of the Singapore government. It effectively owns 420,170,835 shares (28\%) of DBS holdings, of which $15.7 \%$ is owned by Maju Holdings Pte Ltd, a wholly-owned subsidiary of Temasek Holdings (Pte) Ltd.
} 
Hence, while Singapore may be moving towards a more liberalised banking service, it still has some form of monitoring embedded in its financial system in the form of MAS monitoring the smaller banks as well as the government having some share of assets in Singapore's largest bank, DBS. In terms of the level of government involvement, it still plays a substantial role as indicated in Singapore's financial freedom index in the Index of Economic Freedom 2008 produced by the Heritage Foundation. Singapore obtained an index of 50 whereas the top ten economies had financial freedom index ranging between 70 and 90 thus showing the level of government involvement in Singapore financial services.

The aim of this paper is two-fold. First, we measure and attempt to explain productivity change in the deposits-loans segment of the banking industry. Second, to seek out and determine whether the merger of local banks as a result of deregulation improved productivity over the period 1995 to 2005. The estimates of productivity growth in Singapore's banking over the period 1995-2005 are derived using the Malmquist productivity index. This approach has two distinguishing features which makes it ideal for a study such as this. First, it does not require prices of resources used and services provided, and it does not require a behavioural assumption such as profit maximisation in competitive markets. Second, sources of any productivity change are established by decomposing the Malmquist productivity index into changes in productive efficiency (catching-up up to the best-practice frontier) and changes in the production frontier (technological change). While a myriad of factors may have contributed to changes in bank productivity over this period, deregulation is arguably the most significant event within the banking sector.

The paper is divided into five sections. Section 2 describes the Malmquist 
productivity index and its decomposition. Section 3 describes the inputs and outputs employed and the limitations faced. Section 4 presents the results in terms of productivity change, technological change and efficiency change and assess their significance in relation to deregulation. The paper concludes with some brief remarks.

\section{Malmquist Productivity Index}

The current study employs the nonparametric input-oriented Malmquist productivity index that decomposes productivity change into technical change and technical efficiency change. This approach has been adopted by many studies analysing productivity at the industry level, including Färe, Grosskopf, Lindgren, \& Roos (1992) in the pharmaceutical industry, Hjalmarsson and Veiderpass (1992) in electricity retail distribution and Price and Weyman-Jones (1996) in the gas industry, among others. In terms of banking and finance services, related studies include Berg, Forsund and Jansen (1992), Fukuyama (1995), Gilbert and Wilson (1998), Worthington (1999), Rebelo and Mendes (2000), Alam (2001), Mukherjee, Ray and Miller (2001), Isik and Hassan (2003), Casu, Girardone and Molyneux (2004), Sturm and Williams (2004) and Rezitis (2006).

\section{INSERT FIGURE 1}

The framework can be illustrated by Figure 1 following Färe, Grosskopf, Norris and Zhang (1994), and Coelli, Rao and Battese (1998). In this diagram, a production frontier representing the efficient level of output $(y)$ that can be produced from a given level of input $(x)$ is constructed, and the assumption made that this frontier can shift over time. The frontiers $(F)$ thus obtained in the current $(t)$ and future $(t+1)$ time 
periods are labelled accordingly. When inefficiency is assumed to exist, the relative movement of any given financial institution over time will therefore depend on both its position relative to the corresponding frontier (technical efficiency) and the position of the frontier itself (technical change). If inefficiency is ignored, then productivity growth over time will be unable to distinguish between improvements that derive from a financial institution 'catching up' to the frontier, or those that result from the frontier itself shifting up over time.

Now for any given financial institution in period $t$, say, represented by the output/input bundle $z_{t}$, the inputs used are $x_{t}$ and the output is $y_{t}$. But this is technically inefficient since the financial institution lies below the production frontier: with the available technology and the same level of inputs the financial institution should be able to produce output $y_{a}$. In the next period there is a technology increase such that more outputs can be produced for any given level of inputs: the frontier moves upward to $F_{t+1}$. Assume the financial institution's output/input bundle is now represented by $z_{t+1}$ with input $x_{t+1}$ and output $y_{t+1}$. Once again the financial institution is inefficient, but in reference to the new technology, and should be producing output $y_{c}$ if it was efficient. The challenge for productivity assessment is to sort these increases in output relative to the level of inputs into that associated with the change in efficiency and that associated with the change in technology.

It is possible using the input-orientated Malmquist productivity index to decompose this total productivity change between the two periods into technical change and technical efficiency change. Input-orientation refers to the emphasis on the 
equiproportionate reduction of inputs, within the context of a given level of output. Studies such as Berg, Forsund and Jansen (1992), Fare, Grosskopf and Lovell (1994), Fukuyama (1995), Gilbert and Wilson (1998), and Rebelo and Mendes (2000) employed this approach. Following Fare, Grosskopf and Lovell (1994), the inputoriented Malmquist productivity change index is expressed as:

$$
M_{t+1}^{I}\left(y_{t+1}, x_{t+1}, y_{t}, x_{t}\right)=\left[D_{t}^{I}\left(y_{t+1}, x_{t+1}\right) / D_{t}^{I}\left(y_{t}, x_{t}\right)\right] \times\left[D_{t+1}^{I}\left(y_{t+1}, x_{t+1}\right) / D_{t+1}^{I}\left(y_{t}, x_{t}\right)\right]^{1 / 2}
$$

where the superscript $I$ indicates an input-orientation, $M$ is the productivity of the most recent production point $\left(x_{t+1}, y_{t+1}\right)$ (using period $t+1$ technology) relative to the earlier production point $\left(x_{t}, y_{t}\right)$ (using period $t$ technology), $D$ are input distance functions, and all other variables are as previously defined. Values greater than unity indicate positive total factor productivity (TFP) growth between the two periods. An equivalent way of writing this index is:

$$
\begin{aligned}
& M_{t+1}^{I}\left(y_{t+1}, x_{t+1}, y_{t}, x_{t}\right)=\left[D_{t+1}^{I}\left(y_{t+1}, x_{t+1}\right) / D_{t}^{I}\left(y_{t}, x_{t}\right)\right] \times \\
& {\left[\left(D_{t}^{I}\left(y_{t+1}, x_{t+1}\right) / D_{t+1}^{I}\left(y_{t+1}, x_{t+1}\right)\right) \times\left(D_{t}^{I}\left(y_{t}, x_{t}\right) / D_{t+1}^{I}\left(y_{t}, x_{t}\right)\right)\right]^{1 / 2}}
\end{aligned}
$$

or

$$
M=E \cdot P
$$

Where

$$
\begin{gathered}
E=\left[D_{t+1}^{I}\left(y_{t+1}, x_{t+1}\right) / D_{t}^{I}\left(y_{t}, x_{t}\right)\right] \\
P=\left[\left(D_{t}^{I}\left(y_{t+1}, x_{t+1}\right) / D_{t+1}^{I}\left(y_{t+1}, x_{t+1}\right)\right) \times\left(D_{t}^{I}\left(y_{t}, x_{t}\right) / D_{t+1}^{I}\left(y_{t}, x_{t}\right)\right)\right]^{1 / 2}
\end{gathered}
$$

and $M$ (Malmquist TFP) is the product of a measure of technical progress $P$ as measured by shifts in the frontier measured at period $t+1$ and period $t$ (the geometric mean of the two ratios in the square bracket) and a change in efficiency $E$ over the 
same period (the term outside the square bracket). Using this approach, four efficiency/productivity indices are provided for each financial institution along with a measure of technical progress over time. These are: (i) technical efficiency change (i.e. relative to a constant returns-to-scale technology); (ii) technological change; (iii) pure technical efficiency change (i.e. relative to a variable returns-to-scale technology); (iv) scale efficiency change; and (v) TFP change. It is important to make a note here that the scale efficiency obtained is not the real returns to scale as it is constructed, in each period, as the ratio of the distance function satisfying constant returns to scale to the distance function restricted to satisfy variable returns to scale. Coelli, Rao \& Battese (1998) discuss the linear programs necessary to calculate these indices and the DEAP Version 2.1 software used in this analysis.

\section{Data and Input/Output Specification}

The data consist of annual observations of twenty-six commercial banks over the period 1995 to 1999 and ten commercial banks over the period 2000 to 2005. The data are drawn from the audited financial statements of the banks, purchased from the Accounting and Corporate Regulatory Authority (ACRA) (previously known as the Registry of Companies and Businesses) in Singapore. Seven other commercial banks were excluded through the technical requirement for a balanced panel of data: the Bank Nationale De Paris, Paribas Merchant Banking Asia, Bank of Tokyo, Union Bank of Switzerland, Mitsubishi Bank, Tat Lee Bank, and HSBC Investment Bank.

The current study is an extension of Leong and Dollery (2004) which focused solely on the commercial banks. Following their approach on building a sample 
representative of the banking industry, Singapore banks were carefully selected on three criteria. First, the sample was restricted to locally incorporated commercial banks and foreign banks with full, restricted and offshore licenses. Smaller merchant banks, finance companies, and other financial institutions were filtered out using industry statistics compiled by the KPMG (1997) Survey of Banking and Financial Institutions in Singapore. Second, only commercial banks focused on lending markets were included in the sample. Third, only the largest banks in terms of total assets within these categories were selected but largely dependent on availability of archived data from ACRA. The sample size of 26 banks is nonetheless in some way still representative of the banking industry. Bank sizes ranging from SG\$1.9 billion to SG\$106 billion in 2000 allows the study to analyse productivity growth based on the utilisation of inputs and not driven by the institution size which is not a focus of the current study.

The issue of determining outputs and inputs is highly dependent on the development process on what banks actually produce. This has been an on-going contentious issue in the banking literature (see Berger and Humphrey, 1992). In general, there are two main approaches to classifying outputs and inputs; the production approach and the intermediation approach. The production approach employed in studies like Sherman and Gold (1985), Berg, Forsund and Jansen (1992), Berg and Humphrey (1992), and Drake (2001) consider deposit-taking institutions as the producers of services associated with the loans and deposit accounts. Hence, loans and deposits are 'produced' with inputs like capital and labour. In contrast, the intermediation approach consider financial institutions as intermediaries and that the sole purpose of banks is to raise funds through deposits and/or borrowed wholesale funds (managed 
liabilities) and transform these into loans and other earning assets. This approach thus identifies loans and other earning assets as outputs while deposits and borrowed funds together with capital and labour as inputs. Studies that adopted the intermediation approach include Millar and Noulas (1996), Gilbert and Wilson (1998), Rebelo and Mendes (2000), and Drake (2001).

In the context of Singapore's commercial banks, Leong and Dollery (2004) noted that the quantum of high value-added deposits compared to time and savings deposits is relatively small. Further, given the fact that foreign banks are legally restricted in their ability to accept Singapore dollar deposits, this would imply that their revenue share of interest-bearing assets would be larger than deposits (Leong and Dollery, 2004). It is based on these rationales that the current study employs the intermediation approach and identifies one output: loans to non-bank customers $\left(y_{1}\right)$ and three inputs: customer deposits $\left(x_{1}\right)$, fixed assets $\left(x_{2}\right)$, and personnel/staff costs $\left(x_{3}\right)^{5}$. All monetary values are converted into 2000 prices using the GDP deflator of financial and business services drawn from various issues of the Yearbook of Statistics published by the Department of Statistics, Singapore.

\footnotetext{
${ }^{5}$ Fixed assets are made up of motor vehicles, equipment, furniture and fittings, and leasehold improvements. This implies that fixed assets refer to physical inputs or physical capital which excludes assets such as loans and securities. The adoption of fixed assets as inputs follows the intermediation approach as employed in studies such as Grifell-Tatje and Lovell (1996); Gilbert and Wilson (1998); Worthington (1999); Alam (2001); and Drake (2001). In regards to number of employees which is used in other studies, the current study uses staff costs. Conventionally, the former would be used but as some banks’ financial statements did not provide this information, we used staff costs as a proxy to labour input.
} 
It is important to note that some banks do not provide the personnel/staff costs $\left(x_{3}\right)$ input for the years 1995 and 1996. Since the focus of this paper is the efficiency performance before and after deregulation, a two-stage approach of the Malmquist productivity index is adopted. First, for the years 1995 to 1999, which represents the period before deregulation, only two inputs, customer deposits $\left(x_{1}\right)$ and fixed assets $\left(x_{2}\right)$ are considered. Second, from 1999 to 2005 which represents the period of deregulation, all three inputs are used as these data are available from the financial statements of each bank.

For the period 2000-2005, the sample size was reduced from 26 to 10 due to the

following reasons. First, the reduced sample was due to a significant portion of Japanese banks (Singapore branches) having shutdown from 1997 onwards due to bankruptcies faced by major financial institutions in Japan. This is further worsened by the recession in Japan from 1997 to 1998. Second, some other banks, including the Deutsche Bank Aktiengesellschaft, Calyon Merchant Bank Asia Ltd and Credit Suisse (Singapore) Ltd, were excluded due to missing data in their annual reports/financial statements for certain years. Barclays Bank PLC was excluded as its data provided unusual figures in loans.

\section{Empirical results}

Table 2 reports the sample means of inputs and outputs by year for the period 19951999 while Table 3 reports the same information for the period 1999-2005. Before 
deregulation, the most interesting indication is the low average annual growth rate of loans (output) compared to its inputs. Largely accounting for the poor growth was the onset of the Asian financial crisis in 1997. Although Singapore weathered the Asian financial crisis better than many Asian economies, it was still affected by it due to its close economic integration with other regional economies. The effects flowed-on to the wholesale and retail trade, hotels and restaurants, as well as its financial services sector, with a slowdown in growth in these sectors. In turn the effects reduced the level of loans as well as the accumulated level of fixed assets.

\section{INSERT TABLE 2}

\section{INSERT TABLE 3}

Since 2000, with the gradual implementation of deregulation and recovery from the financial crisis, growth rates for loans have improved at an average rate of 6.60 percent per annum. However, when compared to the growth rates of inputs, this would suggest that there was little productivity growth. The above comparisons of means, while interesting, do not provide any productivity change analysis. Such an analysis is based on the Malmquist indices of productivity as detailed in Section 2 based on the assumption that banks operate under constant returns-to-scale. These results are presented and analysed below.

Three primary results are derived from the Malmquist indices of productivity growth over the sample period. First, the measurement of productivity change. Second, the decomposition of productivity change into efficiency change (i.e. a 'catch-up’ effect) and technological change (i.e. a 'frontier-shift' or 'best-practice frontier' effect). Third, the 'catch-up' effect is further decomposed into technical efficiency and scale efficiency: this helps explain the main sources of improvement.

\section{INSERT TABLE 4}


Table 4 shows the mean annual figures for total factor productivity (henceforth TFP), efficiency change and technological change, as well as the number of banks on or above the frontier for the periods 1995-1999 and 2000-2005. On examining the changes in productivity, efficiency and technology for the period 1995 to 1999, there was a mean increase in TFP of 1.2 percent due to improvements in efficiency (48.8 percent), but dampened by a decrease in technological change by 32 percent. Table 4 clearly shows efficiency change being the main driver of TFP. It is interesting to note that TFP in 1998 was below unity due to a decline in efficiency change, rather than technological change because of the effects of the Asian financial crisis. The implication from this is that many of the banks (19 of them) must have improved through best-practice measures in reaction to the contagion from the Asian financial crisis. For the period 2000 to 2005, mean TFP fell by 3.6 percent due to technological regress although there was evidence of ‘catch-up' of around 23.4 percent. A finding that is similar to studies on banks is the efficiency change score. The relatively high efficiency change scores, before and after deregulation, are in line with other studies on banking efficiency such as Elyasiani and Mehdian (1995) for US banks, Favero and Papi (1995) for Italian banks, and Christopoulos and Tsionas (2001) for Greek banks.

In regards to technological change, its mean score in post-deregulated period compared to the previous period showed signs of improvement (from -32 percent to 21.9 percent), whereas for technical change, this fell from 48.8 percent to 23.4 percent. What this suggests is that in general, banks have begun to adopt best-practice with the adoption of new forms of innovation to improve banking services such as ebanking which improves efficiency and enhances competition and convenience to customers. This is evident from Table 4, which shows technological change of over 
1.00 in 2004 and 2005. Prior to 2004, technological change of less than 1.00 reflects most banks still in the process of introducing e-banking as part of their service. $\mathrm{Wu}$, Hsia and Heng (2006) identified that e-banking was a disruptive innovation for the incumbent banks and required massive changes in the areas of both technological knowledge and business model. Such change require significant amounts of time and thus from 2000 to 2003, the technological change was less than unity.

An interesting issue to note is that with the onset of deregulation of Singapore's banking services, the period 2000-05 exhibit lower TFP than before liberalisation. Economic theory dictates that with deregulation, the level of competition increases and in turn improves efficiency and productivity. Whilst this may not seem to hold true from the findings of Table 4, it is important to note that the sample size differs between the two periods and that the TFP score that is being examined is only an average score which may be exaggerated as a result of poor performance by just a few banks (ie. outliers). A more concise analysis on TFP would be at the firm level which is examined in Section 4.2. Nevertheless, to ascertain the contributions to the fall in mean TFP between these two periods, we further examine efficiency change as this indicator showed a deprovement between the two periods. Efficiency change is decomposed into pure technical efficiency and scale efficiency and their scores are presented in Table 5.

\section{INSERT TABLE 5}

As mentioned earlier the main driver of TFP change for both periods was efficiency change. A decomposition of this indicator into pure technical efficiency (PTE) and scale efficiency (SE) would provide more evidence for TFP growth. For the period 1995-1999, most banks were operating efficiently except for the year 1998, which 
exhibits the effects of the Asian financial crisis in 1997. In 1998, 17 banks were operating inefficiently, indicating that these banks could have saved, on average, 25.3 percent of (that is, $1-\mathrm{E}$ ) in input quantities if they had adopted best practice technology. The productivity losses for this year are attributed to the decrease in scale efficiency of around 33.4 percent (1 - SE) which indicates failure to adopt bestpractice management. This is expected when investments in banks fall during a financial turmoil resulting in surplus resources and thus poor allocation of available resources. For the period 2000-2005, most banks were operating efficiently with both technical efficiency and scale efficiency contributing towards the change in efficiency with some meaningful “catch-up”.

Tables 6 and 7 present the mean productivity scores for each bank for the periods 1995-99 and 2000-05, respectively. The main aspect of this part of the discussion is to determine whether the local banks have shown any productivity improvement before and after deregulation of the Singapore financial services. The local banks are OUB holdings, KTB Ltd, UOB holdings, DBS Bank Ltd, and OCBC Holdings. For the period 1995-99, of the 26 banks, 12 had a TFP score above 1.00 which indicates productivity growth. Amongst these 12 banks, 9 of which are mainly investment or merchant banking operations and have TFP scores above the retail banks. These are Credit Suisse (Singapore) Ltd, Societe Generale Asia (Singapore) Ltd, Bank of America (Singapore) Ltd, Morgan Guaranty Trust Company of New York, JP Morgan Chase Bank, N.A., Deutsche Bank Aktiengesellschaft, Royal Bank of Canada, and The Industrial Bank of Japan Ltd. One postulate is that these banks are more nimble and globally focused business with very diverse portfolios. This meant that their production functions were more geographically diversified and would thus emerged 
less battered by the Asian financial crisis compared to their domestically oriented retail peers.

\section{INSERT TABLE 6}

The local banks performed modestly in that 2 of the 5 local banks had TFP over 1.00, namely OUB Holdings and KTB Ltd. TFP growth for UOB holdings and DBS Bank Ltd fell by 5.7 percent and 8.3 percent, respectively. OCBC Holdings was the worst performer amongst the local banks with TFP growth falling by 11.5 percent. All five local banks however experienced some form of ‘catch-up’ attributed to improvements in pure technical efficiency - OUB Holdings (3.239), UOB holdings (3.03), DBS Bank Ltd (3.744) and OCBC Holdings (3.394).

\section{INSERT TABLE 7}

In the deregulated period, there was some improvement in TFP amongst the local banks. OCBCs' improvement in TFP from -11.5 percent to 0.7 percent would suggest that the merger with KTB was the driving force. This outcome is supported by observing the scale efficiency, whereby OCBC improved from -59.5 percent to 27.5 percent which would imply improvements in operating size and management practices. OCBC’s improvement in technological change (from 0.644 to 0.713 ) also suggest the benefits gained from best-practices as a result of acquiring the Bank of Singapore Limited (BOS) in 2000, which during the dot-com era in 2000, was Singapore's first pure internet bank. The merger of UOB and OUB had similar results to the OCBC merger. UOBs' TFP of 0.2 percent in the deregulated period was about the average of OUB (1.4 percent) and UOB (-5.7 percent) in the pre-deregulated period. With the merger, the improvements are clearly shown in the scale-efficiency scores from 0.432 (OUB) and 0.436 (UOB) to 1.195 (OUB merged). DBS experienced TFP growth higher than pre-deregulated period with its merger with 
POSB in 1998. The above analysis would suggest that deregulation which leads to mergers improves efficiency as mergers remove the redundancies and raises the level of efficiency.

The performance of the Singaporean branches of foreign banks also showed some unusual results. First, Bank of America improved in TFP from 33.3 percent to 42.4 percent largely due to improvements in technological change from -35 percent in the period 1995-99 to a growth rate of 12.6 percent in 2000-05. Decomposing the efficiency change into technical efficiency and scale efficiency shows the latter falling from 2.052 to 1.265. Second, Standard Chartered Bank improved in TFP from 4.1 percent in 1995-99 to 12.9 percent in 2000-05 with improvements made in technological change indicating a move towards best-practice decision-making. Third, Dresdner Bank Aktiengesellschaft showed significant improvement with a TFP growth from -43.2 percent in 1995-99 to 8.7 percent in 2000-05. The main improvement was largely in both efficiency change (-11.2 percent to 46.3 percent) and technological change (-36.1 percent to-25.7 percent). The significant improvement in efficiency change is attributed to pure technical efficiency from -15.7 percent to 39.7 percent for the same periods. Fourth, Citibank N.A. experienced significant TFP growth from -7.4 percent in 1995-99 to 1.6 percent in 2000-05 largely driven by technological change: there was no ‘catch-up'. Finally JP Morgan Chase Bank, Mizuho Corporate Bank Ltd and Royal Bank of Canada fared poorly in the deregulated period with falls in TFP from 29.9 to -8.1 percent, -16 to -31.1 , and 17.1 to -34.5 percent, respectively. Falling TFP for JP Morgan Chase Bank and Royal Bank of Canada was attributed to deterioration in efficiency change, primarily scale 
efficiency while for Mizuho Corporate Bank’s poor performance this was attributed to falling pure technical efficiency from 36.7 to 0 percent.

In this section, we test our reliability of results using a similar bootstrap approach as outlined by Simar and Wilson (1999). Confidence intervals at 0.05 level are estimated in order to determine whether changes in productivity, efficiency or technology are statistical significan. As our sample size is rather small, bootstrapping replicates our dataset to generate an appropriate large number of pseudosamples which in our case is $\mathrm{B}=200$. Tables 8,9 and 10 present the changes in productivity, efficiency and technology for the 26 banks for the period 1995-1999. The results show that majority of our estimates are statistically significant. It is important to note certain outliers such as Morgan Guaranty Trust Company of New York and Societe Generale Asia (Singapore) Ltd. The abnormality of their results is due to significant variations in the reported data in their annual reports. For Morgan Guaranty Trust Company of New York, the number of loans to customers increased by 3,568\% for the period 1996-1997 and for Societe Generale Asia, the number of deposits fell by $90 \%$. In regards to the period 1999-2005, results of changes in productivity, technical and technology for 10 banks shown in Tables 11, 12 and 13 are statistically significant at 0.05 level.

INSERT TABLE 8

INSERT TABLE 9

INSERT TABLE 10

INSERT TABLE 11

INSERT TABLE 12

INSERT TABLE 13 


\section{Concluding Remarks}

This paper analysed productivity growth in Singapore's banking sector before and following deregulation. Using a two-stage approach, the Malmquist productivity index allowed a comparison of the changes in productivity in terms of efficiency change and technological change between the pre-deregulated period and postderegulated period. Two outcomes were revealed in our findings. First, the results from our study follow a similar pattern to Gilbert and Wilson (1998) for Korean banks, Mukherjee, Ray and Millar’s (2001) for US banks, Casu, Girardone and Molyneux (2004) on European banks, and Rezitis (2006) on Greek banks that deregulation improves productivity growth. In the deregulated period, 7 of the 10 banks experienced some productivity growth, mainly driven by improving best practices (technological change). Second, although no significant 'catch-up' was evident, deregulation improved operational size (i.e. scale efficiency) with the several bank mergers. This was one of the main findings in the current study which aimed at determining the outcome from the mergers of local banks.

Whilst the study has provided some promising results, it should be noted that one of the main limitations of the current study was the use of a small sample size for the second period. A large sample size would have provided more robust results, especially when using the Malmquist productivity index model. Nonetheless, this is a first step towards examining the level of efficiency of Singapore banks since deregulation. Future studies on this would aim at not only increasing the sample size, 
but to improve on the data outputs where available, such as non-lending activities (securities), risk-adjusted off-balance sheet items, and other earning assets. The study also included a brief statistical inference using a bootstrap approach. The results of which are statistically significant inferring that the Malmquist results can be relied upon.

So has Singapore benefited from deregulating its banking sector? In the years since 2000, there has been some improvement, although it is relatively insignificant. This was the immediate response to the growing foreign competition which resulted in the mergers of many local banks into just a few conglomerates. However, as shown in Lindblom (1994) and the recent crisis of mortgage defaults experienced by some of the major US banks in 2007, complete liberalised financial services can still falter largely due to failure in risk-management and the lack of appropriate countermeasures (ie. like a prudential authority or governing body overseeing the operations). In the case of Singapore, the process of deregulation is ongoing, and as such it is still in its infancy in terms of deregulation. However, with a governing body like the MAS whose role is to supervise and monitor the operations of banks, and Singapore's sound economic management which has weathered the effects of the Asian Financial Crisis, Singapore is no-doubt in a position prepared for such a crisis. 


\section{References}

Alam, IMS (2001). A Nonparametric Approach for Assessing Productivity Dynamics of Large U.S. Banks. Journal of Money, Credit and Banking, 33 (1), 121-139.

Tan, A (2001). BG Lee: Singapore to Stay Open to Global Players, Business Times, June 3.

Ball, M (1994). The 1980s property boom. Environment and Planning A, 26, 671-695.

Bartholomew, PF (1994). Comparing Depository Institution Difficulties in Canada, the United States and the Nordic Countries. The Journal of Housing Research, 5 (2), 303-309.

Berg, SA, FR Forsund and ES Jansen (1992). Malmquist indices of productivity growth during the deregulation of Norwegian banking, 1980-89. Scandinavian Journal of Economics, 94, S211-S228.

Berger, A and D Humphrey (1992). Measurement and Efficiency Issues in Commercial Banking. In Output Measurement in the Services Sectors, Z Griliches (ed), Chicago Ill: University of Chicago Press.

Casu, B, C Girardone and P Molyneux (2004). Productivity change in European banking: A comparison of parametric and non-parametric approaches. Journal of Banking \& Finance, 28, 2521-2540.

Christopoulos, D and EG Tsionas (2001). Banking Economic Efficiency in the deregulation period: Results from heteroscedastic stochastic frontier models. The Manchester School, 69, 656-676.

Coelli, T, DS Prasada Rao and GE Battese (1998). An Introduction to Efficiency and Productivity Analysis, Boston MA: Kluwer Academic Publishers. 
Drake, L (2001). Efficiency and productivity change in UK banking. Applied Financial Economics, 11, 557-571.

Elyasiani, E and SM Mehdian (1995). The Comparative Efficiency performance of small and large commercial banks in the pre and post deregulation eras. Applied Economics, 27, 1069-1079.

Färe, R, S Grosskopf and CAK Lovell (1994). Production Frontiers, Cambridge: University Press Cambridge.

Färe, R, S Grosskopf, B Lindgren and P Roos (1992). Productivity Developments in Swedish pharmacies 1980-1989: A non-parametric approach. Journal of Productivity Analysis, 3 (1-2) 85-101.

Färe, R, S Grosskopf, M Norris and Z Zhang (1994). Productivity growth, technical progress, and efficiency change in industrialized countries. American Economic Review, 84(1), 66-83.

Favero, CA and L Papi (1995). Technical Efficiency and scale efficiency in the Italian banking sector: A non-parametric approach. Applied Economics, 27, 385-395.

Fukuyama, H (1995). Measuring efficiency and productivity growth in Japanese banking: a nonparametric frontier approach. Applied Financial Economics, 5, 95107.

Gilbert, RA and PW Wilson (1998). Effects of Deregulation on the Productivity of Korean Banks. Journal of Economics and Business, 50, 133-155.

Grifell-Tatje, E and CAK Lovell (1996). Deregulation and productivity decline: The case of Spanish savings banks. European Economic Review, 40, 1281-1303. 
Hjalmarsson, L and A Veiderpass (1992). Efficiency and ownership in Swedish electricity retail distribution. Journal of Productivity Analysis, 3, 7-23.

Isik, I and MK Hassan (2003). Financial deregulation and total factor productivity change: An empirical study of Turkish commercial banks. Journal of Banking and Finance, 27, 1455-1485.

KPMG (1997). Survey of Banking and Financial Institutions in Singapore, KPMG Peat Marwick Consultants, Singapore.

Leong, WH and B Dollery (2004). The Productive Efficiency of Singapore Banks: An Application and extension of the Barr et al. (1999) Approach. The Singapore Economic Review, 49 (2), 273-290.

Lindblom, T (1994). Credit Losses in Nordic Banks. In The Changing Face of European Banks and Securities Markets, Jack Revell (ed.), UK/St Martin’s: Macmillan.

Monetary Authority of Singapore (1997/98). Annual Report, Singapore.

Monetary Authority of Singapore (1999). Liberalising Commercial Banking and Upgrading Local Banks, Statement by the Monetary Authority of Singapore, May, Singapore.

Millar, SM and AG Noulas (1996). The technical efficiency of large bank production. Journal of Banking and Finance, 20, 495-509.

Mukherjee, K, SC Ray and SM Miller (2001). Productivity growth in large US banks: The initial postderegulation experience. Journal of Banking and Finance, 25 (5), 913-939. 
Price, CW and T Weyman-Jones (1996). Malmquist Indices of Productivity Change in the U.K. Gas Industry Before and After Privatization. Applied Economics, 28, 2939.

Rebelo, J and V Mendes (2000). Malmquist Indices of Productivity Change in Portuguese Banking: The Deregulation Period. International Advances in Economic Research, 6(3), 531-543.

Rezitis, AN (2006). Productivity Growth in the Greek Banking Industry: A NonParametric Approach. Journal of Applied Economics, 9 (1), 119-138.

Sherman, HD and F Gold (1985). Bank branch operation efficiency: evaluation with data envelopment analysis. Journal of Finance, 9, 297-316.

Simar, L and PW Wilson (1999). Estimating and Bootstrapping Malmquist Indices. European Journal of Operational Research, 115, 459-471.

Sturm, JE and B Williams (2004). Foreign Bank Entry, Deregulation and Bank Efficiency: Lessons from the Australian Experience. Journal of Banking and Finance, 28 (7), 1775-99.

Worthington, AC (1999). Malmquist Indices of Productivity Change in Australian Financial Services. Journal of International Financial Market, Institutions and Money, 9 (3), 303-320.

Wu, JH, TL Hsia and SH Heng (2006). Core Capabilities for Exploiting Electronic Banking. Journal of Electronic Commerce Research, 7 (2), 111-122. 
Table 1. Number of commercial banks in Singapore by license type, 1998-2006

\begin{tabular}{lrrrrrrrrr}
\hline & $\mathbf{1 9 9 8}$ & $\mathbf{1 9 9 9}$ & $\mathbf{2 0 0 0}$ & $\mathbf{2 0 0 1}$ & $\mathbf{2 0 0 2}$ & $\mathbf{2 0 0 3}$ & $\mathbf{2 0 0 4}$ & $\mathbf{2 0 0 5}$ & $\mathbf{2 0 0 6}$ \\
\hline Local $^{\text {a }}$ & 12 & 9 & 8 & 8 & 6 & 5 & 5 & 5 & 5 \\
Foreign & 22 & 22 & 23 & 23 & 22 & 22 & 23 & 24 & 24 \\
Wholesale & 13 & 13 & 16 & 20 & 33 & 31 & 37 & 35 & 34 \\
Offshore & 107 & 98 & 93 & 82 & 59 & 59 & 50 & 47 & 45 \\
Total & 154 & 142 & 140 & 133 & 120 & 117 & 115 & 111 & 108 \\
\hline $\begin{array}{l}\text { Notes: All local banks are full banks. Figures at March end. } \\
\text { Source: MAS Annual Report, 2005/06. }\end{array}$
\end{tabular}




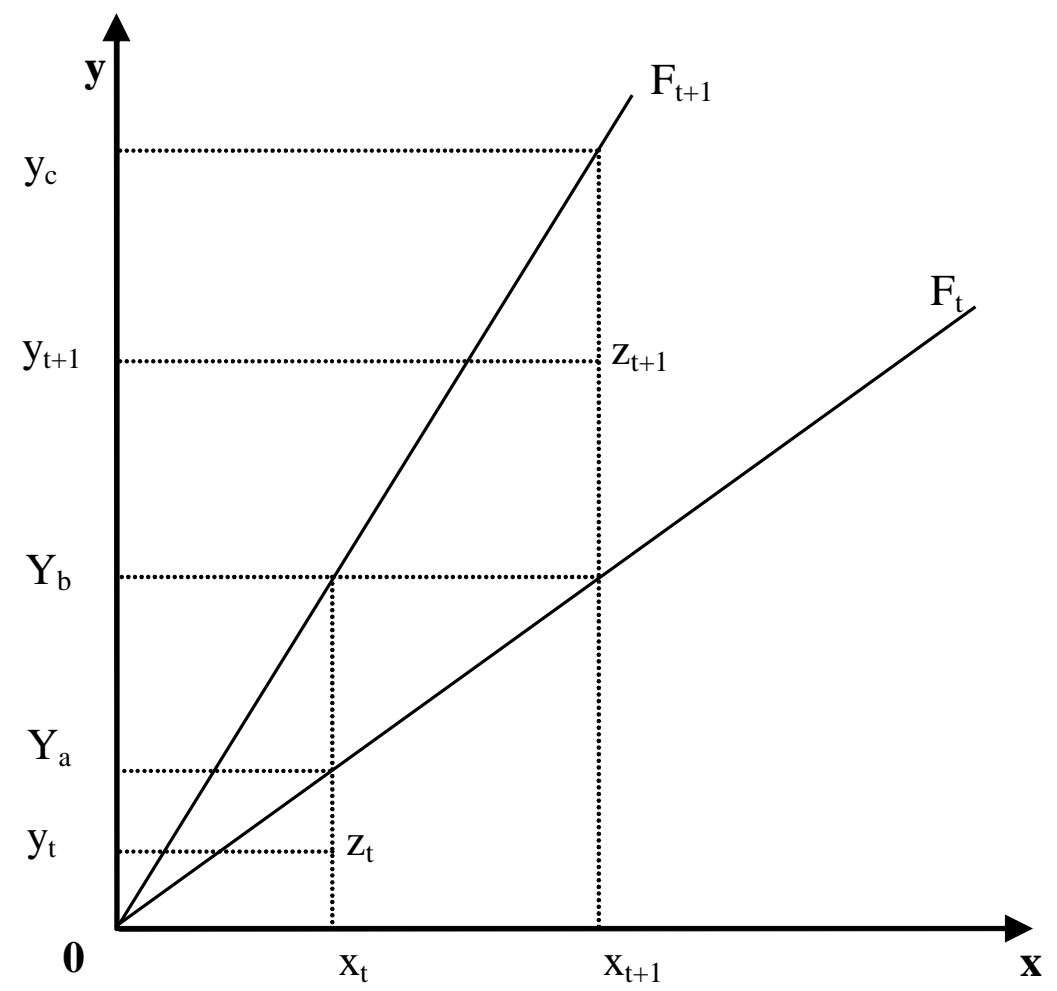

Figure 1. Malmquist index and productivity change over time 
Table 2: Means of inputs and outputs, 1995 - 1999 (in millions of SG\$ at 2000 prices),

\begin{tabular}{|c|c|c|c|c|c|c|}
\hline & 1995 & 1996 & 1997 & 1998 & 1999 & $\begin{array}{c}\text { Average } \\
\text { Annual growth } \\
\text { rate, } \\
\text { 1995-1999 }\end{array}$ \\
\hline y1: loans to non-bank customers & 8,060 & 10,103 & 10,852 & 9,921 & 8,840 & 2.31 \\
\hline x1: customer deposits & 5,677 & 7,202 & 8,108 & 9,470 & 10,815 & 16.11 \\
\hline $\mathrm{x} 2$ : fixed assets & 116 & 150 & 111 & 185 & 204 & 14.11 \\
\hline
\end{tabular}

Note: Mean is the average of 26 financial institutions. 
Table 3: Means of inputs and outputs, 1999 - 2005 (in millions of SG\$ at 2000 prices),

\begin{tabular}{|c|c|c|c|c|c|c|c|c|}
\hline & 1999 & 2000 & 2001 & 2002 & 2003 & 2004 & 2005 & $\begin{array}{l}\text { Ave. } \\
\text { Annual } \\
\text { growth } \\
\text { rate, } \\
1999- \\
2005\end{array}$ \\
\hline $\begin{array}{l}\text { y1: loans to non- } \\
\text { bank customers }\end{array}$ & 15,500 & 15,296 & 20,573 & 18,504 & 21,562 & 23,100 & 23,032 & 6.60 \\
\hline $\begin{array}{l}\text { x1: customer } \\
\text { deposits }\end{array}$ & 21,485 & 21,822 & 28,302 & 26,102 & 30,756 & 32,200 & 31,728 & 6.49 \\
\hline $\mathrm{x} 2$ : fixed assets & 426 & 431 & 605 & 540 & 567 & 531 & 526 & 3.51 \\
\hline x3: staff costs & 156 & 187 & 229 & 223 & 247 & 264 & 295 & 10.62 \\
\hline
\end{tabular}

Note: Mean is the average of 10 financial institutions. 
Table 4: TFP, efficiency and technological change scores in Singaporean banks

(annual mean)

\begin{tabular}{|c|c|c|c|c|c|c|c|}
\hline & & \multicolumn{2}{|c|}{ TFP change } & \multicolumn{2}{|c|}{ Efficiency Change } & \multicolumn{2}{|c|}{ Technological Change } \\
\hline & $\begin{array}{c}\text { Number of } \\
\text { Banks }\end{array}$ & Score & $\begin{array}{l}\text { Number } \\
\text { Efficient }\end{array}$ & Score & $\begin{array}{l}\text { Number } \\
\text { Efficient }\end{array}$ & Score & $\begin{array}{l}\text { Number } \\
\text { Efficient }\end{array}$ \\
\hline 1996 & 26 & 1.297 & 20 & 1.463 & 24 & 0.887 & 0 \\
\hline 1997 & 26 & 1.055 & 11 & 2.057 & 22 & 0.513 & 0 \\
\hline 1998 & 26 & 0.756 & 9 & 0.747 & 9 & 1.013 & 19 \\
\hline 1999 & 26 & 1.015 & 10 & 2.185 & 24 & 0.465 & 1 \\
\hline Mean & & 1.012 & & 1.488 & & 0.680 & \\
\hline 2000 & 10 & 1.006 & 4 & 1.672 & 10 & 0.602 & 0 \\
\hline 2001 & 10 & 1.085 & 4 & 1.263 & 7 & 0.859 & 2 \\
\hline 2002 & 10 & 0.822 & 2 & 1.322 & 9 & 0.622 & 1 \\
\hline 2003 & 10 & 0.806 & 5 & 1.210 & 8 & 0.666 & 2 \\
\hline 2004 & 10 & 1.302 & 7 & 1.291 & 7 & 1.009 & 9 \\
\hline 2005 & 10 & 0.853 & 2 & 0.810 & 1 & 1.053 & 8 \\
\hline Mean & & 0.964 & & 1.234 & & 0.781 & \\
\hline
\end{tabular}


Table 5: Efficiency scores in Singaporean banks, 1996-2005 (annual mean)

\begin{tabular}{|c|c|c|c|c|c|c|c|}
\hline & & Efficie & ange (E) & Pure Tech & Efficiency & Scale E & ncy (SE) \\
\hline & $\begin{array}{c}\text { Number of } \\
\text { Banks }\end{array}$ & Score & $\begin{array}{l}\text { Number } \\
\text { Efficient }\end{array}$ & Score & $\begin{array}{l}\text { Number } \\
\text { Efficient }\end{array}$ & Score & $\begin{array}{l}\text { Number } \\
\text { Efficient }\end{array}$ \\
\hline 1996 & 26 & 1.463 & 24 & 1.000 & 14 & 1.463 & 24 \\
\hline 1997 & 26 & 2.057 & 22 & 2.444 & 25 & 0.841 & 7 \\
\hline 1998 & 26 & 0.747 & 9 & 1.120 & 15 & 0.666 & 14 \\
\hline 1999 & 26 & 2.185 & 24 & 1.812 & 22 & 1.206 & 21 \\
\hline Mean & & 1.488 & & 1.492 & & 0.997 & \\
\hline 2000 & 10 & 1.672 & 10 & 2.127 & 10 & 0.786 & 6 \\
\hline 2001 & 10 & 1.263 & 7 & 1.367 & 10 & 0.923 & 6 \\
\hline 2002 & 10 & 1.322 & 9 & 1.006 & 9 & 1.315 & 8 \\
\hline 2003 & 10 & 1.210 & 8 & 1.122 & 10 & 1.079 & 6 \\
\hline 2004 & 10 & 1.291 & 7 & 1.127 & 10 & 1.146 & 6 \\
\hline 2005 & 10 & 0.810 & 1 & 0.821 & 6 & 0.986 & 3 \\
\hline Mean & & 1.234 & & 1.203 & & 1.026 & \\
\hline
\end{tabular}


Table 6: Ranked TFP scores by individual banks, 1995-1999 (annual mean)

\begin{tabular}{|c|c|c|c|c|c|}
\hline & $\begin{array}{c}\text { Efficiency } \\
\text { Change }\end{array}$ & $\begin{array}{c}\text { Technological } \\
\text { Change }\end{array}$ & $\begin{array}{c}\text { Pure } \\
\text { Technical } \\
\text { Efficiency }\end{array}$ & $\begin{array}{c}\text { Scale } \\
\text { Efficiency }\end{array}$ & TFP \\
\hline Credit Suisse (Singapore) Ltd & 2.803 & 0.792 & 2.177 & 1.287 & 2.219 \\
\hline Societe Generale Asia (Singapore) Ltd & 2.377 & 0.714 & 1.325 & 1.794 & 1.697 \\
\hline Bank of America (Singapore) Ltd & 2.052 & 0.650 & 1.000 & 2.052 & 1.333 \\
\hline Morgan Guaranty Trust Company of New York & 1.794 & 0.726 & 1.443 & 1.243 & 1.303 \\
\hline JP Morgan Chase Bank, N.A. & 2.061 & 0.630 & 1.303 & 1.582 & 1.299 \\
\hline Deutsche Bank Aktiengesellschaft & 1.921 & 0.660 & 1.624 & 1.183 & 1.267 \\
\hline Royal Bank of Canada & 1.811 & 0.646 & 1.393 & 1.300 & 1.171 \\
\hline OCBC Trustee Ltd & 1.578 & 0.731 & 1.743 & 0.905 & 1.154 \\
\hline The Industrial Bank of Japan Ltd & 1.536 & 0.693 & 1.319 & 1.164 & 1.065 \\
\hline Standard Chartered Bank & 1.644 & 0.633 & 1.516 & 1.084 & 1.041 \\
\hline OUB Holdings & 1.399 & 0.725 & 3.239 & 0.432 & 1.014 \\
\hline KTB Ltd & 1.488 & 0.677 & 1.458 & 1.020 & 1.007 \\
\hline Credit Agricole (Suisse) SA & 1.381 & 0.712 & 1.323 & 1.044 & 0.983 \\
\hline The Tokai Bank Ltd & 1.329 & 0.713 & 1.270 & 1.046 & 0.948 \\
\hline UOB Holdings & 1.321 & 0.714 & 3.030 & 0.436 & 0.943 \\
\hline Citibank N.A. & 1.423 & 0.651 & 1.351 & 1.053 & 0.926 \\
\hline DBS Bank Ltd & 1.284 & 0.714 & 3.744 & 0.343 & 0.917 \\
\hline The Sakura Bank & 1.429 & 0.634 & 1.326 & 1.078 & 0.906 \\
\hline OCBC Holdings & 1.375 & 0.644 & 3.394 & 0.405 & 0.885 \\
\hline ABN AMRO Asia Merchant Bank (Singapore) Ltd & 1.300 & 0.665 & 1.000 & 1.300 & 0.865 \\
\hline Mizuho Corporate Bank Ltd & 1.330 & 0.632 & 1.367 & 0.973 & 0.840 \\
\hline Calyon Merchant Bank Asia Ltd & 1.082 & 0.763 & 0.998 & 1.084 & 0.826 \\
\hline Barclays Bank PLC & 1.272 & 0.622 & 1.156 & 1.100 & 0.791 \\
\hline Sumitomo Mitsui Banking Corporation & 1.155 & 0.672 & 1.061 & 1.089 & 0.777 \\
\hline The Asahi Bank Ltd & 1.000 & 0.670 & 1.000 & 1.000 & 0.670 \\
\hline Dresdner Bank Aktiengesellschaft & 0.888 & 0.639 & 0.847 & 1.048 & 0.568 \\
\hline
\end{tabular}


Table 7: Ranked TFP scores by individual banks, 2000-2005 (annual mean)

\begin{tabular}{|l|c|c|c|c|c|}
\hline & Efficiency & Technological & Pure & Scale & TFP \\
& Change & Change & Technical & Efficiency \\
& & & & \\
& & & & \\
\hline Bank of Americiency (Singapore) Ltd & 1.265 & 1.126 & 1.000 & 1.265 & 1.424 \\
\hline Standard Chartered Bank & 1.465 & 0.771 & 1.551 & 0.945 & 1.129 \\
\hline Dresdner Bank Aktiengesellschaft & 1.463 & 0.743 & 1.397 & 1.047 & 1.087 \\
\hline Citibank N.A. & 1.355 & 0.750 & 1.496 & 0.906 & 1.016 \\
\hline UOB Holdings & 1.399 & 0.716 & 1.170 & 1.195 & 1.002 \\
\hline OCBC Holdings & 1.372 & 0.713 & 1.076 & 1.275 & 0.978 \\
\hline DBS Bank Ltd & 1.329 & 0.724 & 1.000 & 1.329 & 0.962 \\
\hline JP Morgan Chase Bank, N.A. & 1.351 & 0.680 & 1.327 & 1.018 & 0.919 \\
\hline Mizuho Corporate Bank Ltd & 0.957 & 0.719 & 1.000 & 0.957 & 0.689 \\
\hline Royal Bank of Canada & 0.676 & 0.968 & 1.176 & 0.575 & 0.655 \\
\hline
\end{tabular}


Table 8: Changes in productivity of 26 banks, 1995-1999

\begin{tabular}{|l|l|l|l|l|}
\hline & $1995-1996$ & $1996-1997$ & $1997-1998$ & $1998-1999$ \\
& & & \\
\hline Bank of America (Singapore) Ltd & 6.092 & 0.723 & 2.030 & $0.353^{*}$ \\
\hline Calyon Merchant Bank Asia Ltd & 0.982 & 0.790 & 0.382 & 1.567 \\
\hline Mizuho Corporate Bank Ltd & 1.176 & 0.879 & 0.688 & 0.700 \\
\hline The Sakura Bank & 1.037 & 0.835 & 1.126 & 0.693 \\
\hline JP Morgan Chase Bank, N.A. & 2.335 & 0.968 & 1.169 & 1.076 \\
\hline Standard Chartered Bank & 1.205 & 1.047 & 1.540 & 0.604 \\
\hline ABN AMRO Asia Merchant Bank (Singapore) Ltd & 1.650 & $0.041^{*}$ & $8.320 *$ & 0.992 \\
\hline Citibank N.A. & 0.889 & 0.923 & 0.983 & 0.913 \\
\hline Credit Agricole (Suisse) SA & 1.048 & 0.857 & 1.039 & 1.000 \\
\hline Deutsche Bank Aktiengesellschaft & 1.342 & 0.950 & 1.320 & 1.531 \\
\hline Dresdner Bank Aktiengesellschaft & 0.193 & 0.842 & 0.667 & 0.958 \\
\hline Societe Generale Asia (Singapore) Ltd & 1.093 & 10.387 & 0.102 & $7.149 *$ \\
\hline Credit Suisse (Singapore) Ltd & 1.519 & 1.404 & 3.339 & 3.407 \\
\hline KTB Ltd & 1.335 & 0.780 & 0.989 & 1.000 \\
\hline DBS Bank Ltd & 1.085 & 1.219 & 0.607 & 0.881 \\
\hline OCBC Holdings & 1.080 & 3.061 & 0.207 & 0.897 \\
\hline UOB Holdings & 1.012 & 0.959 & 0.927 & 0.880 \\
\hline OUB Holdings & 1.021 & 1.072 & 0.914 & 1.058 \\
\hline Barclays Bank PLC & 1.222 & 1.370 & 0.573 & 0.408 \\
\hline Royal Bank of Canada & 6.493 & 0.176 & 0.723 & 2.278 \\
\hline The Industrial Bank of Japan Ltd & 6.725 & 0.299 & 0.939 & 0.682 \\
\hline Sumitomo Mitsui Banking Corporation & 0.695 & 1.057 & 0.579 & 0.855 \\
\hline The Tokai Bank Ltd & 0.860 & 1.005 & 0.942 & 0.991 \\
\hline Morgan Guaranty Trust Company of New York & 1.291 & $50.980 *$ & $0.017 *$ & 2.551 \\
\hline The Asahi Bank Ltd & 0.890 & 0.547 & 1.008 & 0.410 \\
\hline OCBC Trustee Ltd & 1.086 & 3.883 & 0.658 & 0.638 \\
\hline Note: Ast & & \\
\hline
\end{tabular}

Note: Asterisks $\left(^{*}\right)$ denote significant differences from unity at 0.05. 
Table 9: Changes in efficiency of 26 banks, 1995-1999

\begin{tabular}{|l|l|l|l|l|}
\hline & $1995-1996$ & $1996-1997$ & $1997-1998$ & $1998-1999$ \\
& & & & \\
\hline Bank of America (Singapore) Ltd & 6.846 & 2.031 & 1.987 & $0.642^{*}$ \\
\hline Calyon Merchant Bank Asia Ltd & 1.187 & 0.939 & 0.379 & 3.247 \\
\hline Mizuho Corporate Bank Ltd & 1.229 & 2.468 & 0.673 & 1.530 \\
\hline The Sakura Bank & 1.083 & 2.343 & 1.102 & 1.492 \\
\hline JP Morgan Chase Bank, N.A. & 2.624 & 2.717 & 1.145 & 2.212 \\
\hline Standard Chartered Bank & 1.259 & 2.938 & 1.508 & 1.311 \\
\hline ABN AMRO Asia Merchant Bank (Singapore) Ltd & 1.724 & $0.075^{*}$ & $8.357^{*}$ & 2.638 \\
\hline Citibank N.A. & 1.025 & 2.062 & 0.963 & 2.014 \\
\hline Credit Agricole (Suisse) SA & 1.267 & 1.115 & 1.017 & 2.531 \\
\hline Deutsche Bank Aktiengesellschaft & 1.401 & 2.667 & 1.292 & 2.818 \\
\hline Dresdner Bank Aktiengesellschaft & $0.201 *$ & 2.365 & 0.653 & 2.004 \\
\hline Societe Generale Asia (Singapore) Ltd & 1.302 & 12.558 & 0.103 & $19.011^{*}$ \\
\hline Credit Suisse (Singapore) Ltd & 1.587 & 3.941 & $3.269 *$ & 3.018 \\
\hline KTB Ltd & 1.614 & 1.149 & 0.993 & 2.660 \\
\hline DBS Bank Ltd & 1.311 & 1.450 & 0.610 & 2.344 \\
\hline OCBC Holdings & 1.305 & 5.593 & 0.205 & 2.385 \\
\hline UOB Holdings & 1.224 & 1.141 & 0.931 & 2.341 \\
\hline OUB Holdings & 1.234 & 1.410 & 0.894 & 2.460 \\
\hline Barclays Bank PLC & 1.276 & 3.845 & 0.561 & 0.950 \\
\hline Royal Bank of Canada & $7.296^{*}$ & 0.493 & 0.707 & 4.227 \\
\hline The Industrial Bank of Japan Ltd & 7.026 & 0.839 & 0.919 & 1.029 \\
\hline Sumitomo Mitsui Banking Corporation & $0.726^{*}$ & 2.967 & 0.567 & 1.458 \\
\hline The Tokai Bank Ltd & 1.040 & 1.475 & 0.922 & 2.203 \\
\hline Morgan Guaranty Trust Company of New York & 1.560 & 60.642 & $0.017 *$ & 6.340 \\
\hline The Asahi Bank Ltd & 1.000 & 1.000 & 1.000 & 1.000 \\
\hline OCBC Trustee Ltd & 1.313 & 4.619 & 0.661 & 1.546 \\
\hline Note: Astersks $*$ ) & & \\
\hline
\end{tabular}

Note: Asterisks $(*)$ denote significant differences from unity at 0.05 . 
Table 10: Changes in technology of 26 banks, 1995-1999

\begin{tabular}{|l|l|l|l|l|}
\hline & $1995-1996$ & $1996-1997$ & $1997-1998$ & $1998-1999$ \\
& & & \\
\hline Bank of America (Singapore) Ltd & 0.890 & 0.356 & 1.022 & 0.550 \\
\hline Calyon Merchant Bank Asia Ltd & 0.827 & 0.841 & 1.008 & 0.483 \\
\hline Mizuho Corporate Bank Ltd & 0.957 & 0.356 & 1.022 & 0.457 \\
\hline The Sakura Bank & 0.957 & 0.356 & 1.022 & 0.464 \\
\hline JP Morgan Chase Bank, N.A. & 0.890 & 0.356 & 1.022 & 0.486 \\
\hline Standard Chartered Bank & 0.957 & 0.356 & 1.022 & 0.461 \\
\hline ABN AMRO Asia Merchant Bank (Singapore) Ltd & 0.957 & 0.547 & 0.996 & 0.376 \\
\hline Citibank N.A. & 0.868 & 0.448 & 1.022 & 0.453 \\
\hline Credit Agricole (Suisse) SA & 0.827 & 0.769 & 1.022 & 0.395 \\
\hline Deutsche Bank Aktiengesellschaft & 0.957 & 0.356 & 1.022 & 0.543 \\
\hline Dresdner Bank Aktiengesellschaft & 0.957 & 0.356 & 1.022 & 0.478 \\
\hline Societe Generale Asia (Singapore) Ltd & 0.840 & 0.827 & 0.996 & 0.376 \\
\hline Credit Suisse (Singapore) Ltd & 0.957 & 0.356 & 1.022 & $1.129 *$ \\
\hline KTB Ltd & 0.827 & 0.679 & 0.996 & 0.376 \\
\hline DBS Bank Ltd & 0.827 & 0.841 & 0.996 & 0.376 \\
\hline OCBC Holdings & 0.827 & 0.547 & 1.008 & 0.376 \\
\hline UOB Holdings & 0.827 & 0.841 & 0.996 & 0.376 \\
\hline OUB Holdings & 0.827 & 0.760 & 1.022 & 0.430 \\
\hline Barclays Bank PLC & 0.957 & 0.356 & 1.022 & 0.430 \\
\hline Royal Bank of Canada & 0.890 & 0.356 & 1.022 & 0.539 \\
\hline The Industrial Bank of Japan Ltd & 0.957 & 0.356 & 1.022 & 0.663 \\
\hline Sumitomo Mitsui Banking Corporation & 0.957 & 0.356 & 1.022 & 0.586 \\
\hline The Tokai Bank Ltd & 0.827 & 0.681 & 1.022 & 0.450 \\
\hline Morgan Guaranty Trust Company of New York & 0.827 & 0.841 & 0.996 & 0.402 \\
\hline The Asahi Bank Ltd & 0.890 & 0.547 & 1.008 & 0.410 \\
\hline OCBC Trustee Ltd & 0.827 & 0.841 & 0.996 & 0.413 \\
\hline Note: Astersks $*$ ) & & \\
\hline
\end{tabular}

Note: Asterisks $\left({ }^{*}\right)$ denote significant differences from unity at 0.05 . 
Table 11: Changes in productivity of 10 banks, 1999-2005

\begin{tabular}{|l|l|l|l|l|l|l|}
\hline & $1999-2000$ & $2000-2001$ & $2001-2002$ & $2002-2003$ & $2003-2004$ & $2004-2005$ \\
\hline Bank of America (Singapore) Ltd & 1.324 & 4.632 & 0.700 & 1.654 & 1.016 & 1.159 \\
\hline Mizuho Corporate Bank Ltd & 0.593 & 0.655 & 0.571 & 0.403 & 1.216 & 0.980 \\
\hline JP Morgan Chase Bank, N.A. & 0.766 & 0.431 & 2.142 & 0.421 & 3.729 & 0.542 \\
\hline Standard Chartered Bank & 1.233 & 2.194 & 0.805 & 1.083 & 1.079 & 0.816 \\
\hline Citibank N.A. & 1.022 & 0.995 & 1.387 & 1.019 & 1.029 & 0.743 \\
\hline Dresdner Bank Aktiengesellschaft & 3.004 & 0.663 & 0.610 & 0.388 & 3.754 & 0.936 \\
\hline DBS Bank Ltd & 0.828 & 0.929 & 0.847 & 1.056 & 1.057 & 1.091 \\
\hline OCBC Holdings & 0.866 & 1.105 & 0.975 & 1.042 & 0.984 & 0.916 \\
\hline UOB Holdings & 0.825 & 1.707 & 0.813 & 0.993 & 0.956 & 0.928 \\
\hline Royal Bank of Canada & 0.790 & 0.681 & 0.363 & 0.878 & 0.735 & 0.626 \\
\hline & & & & & & \\
\hline
\end{tabular}

Note: Asterisks $(*)$ denote significant differences from unity at 0.05 . 
Table 12: Changes in efficiency of 10 banks, 1999-2005

\begin{tabular}{|l|l|l|l|l|l|l|}
\hline & $1999-2000$ & $2000-2001$ & $2001-2002$ & $2002-2003$ & $2003-2004$ & $2004-2005$ \\
\hline Bank of America (Singapore) Ltd & 2.152 & 1.904 & 1.000 & 1.000 & 1.000 & 1.000 \\
\hline Mizuho Corporate Bank Ltd & 1.000 & 1.000 & 1.000 & 0.708 & 1.206 & 0.901 \\
\hline JP Morgan Chase Bank, N.A. & 1.244 & 0.717 & 3.697 & 1.247 & 3.419 & 0.433 \\
\hline Standard Chartered Bank & 2.132 & 2.398 & 1.243 & 1.726 & 1.032 & 0.874 \\
\hline Citibank N.A. & 1.767 & 1.499 & 2.590 & 1.284 & 0.985 & 0.714 \\
\hline Dresdner Bank Aktiengesellschaft & 4.585 & 0.715 & 1.005 & 1.106 & 3.245 & 0.830 \\
\hline DBS Bank Ltd & 1.432 & 1.381 & 1.560 & 1.929 & 1.010 & 0.918 \\
\hline OCBC Holdings & 1.497 & 1.664 & 1.793 & 1.968 & 0.940 & 0.808 \\
\hline UOB Holdings & 1.427 & 2.510 & 1.534 & 1.656 & 0.914 & 0.900 \\
\hline Royal Bank of Canada & 1.206 & 0.509 & 0.319 & 0.496 & 1.092 & 0.901 \\
\hline & & & & & & \\
\hline
\end{tabular}

Note: Asterisks $(*)$ denote significant differences from unity at 0.05 . 
Table 13: Changes in technology of 10 banks, 1999-2005

\begin{tabular}{|l|l|l|l|l|l|l|}
\hline & $1999-2000$ & $2000-2001$ & $2001-2002$ & $2002-2003$ & $2003-2004$ & $2004-2005$ \\
\hline Bank of America (Singapore) Ltd & 0.616 & 2.433 & 0.700 & 1.654 & 1.016 & 1.159 \\
\hline Mizuho Corporate Bank Ltd & 0.593 & 0.655 & 0.571 & 0.570 & 1.008 & 1.087 \\
\hline JP Morgan Chase Bank, N.A. & 0.616 & 0.602 & 0.579 & 0.337 & 1.091 & 1.253 \\
\hline Standard Chartered Bank & 0.578 & 0.915 & 0.647 & 0.628 & 1.046 & 0.934 \\
\hline Citibank N.A. & 0.578 & 0.664 & 0.535 & 0.794 & 1.044 & 1.041 \\
\hline Dresdner Bank Aktiengesellschaft & 0.655 & 0.928 & 0.607 & 0.351 & 1.157 & 1.127 \\
\hline DBS Bank Ltd & 0.578 & 0.673 & 0.543 & 0.548 & 1.047 & 1.188 \\
\hline OCBC Holdings & 0.578 & 0.664 & 0.544 & 0.530 & 1.047 & 1.134 \\
\hline UOB Holdings & 0.578 & 0.680 & 0.530 & 0.599 & 1.046 & 1.032 \\
\hline Royal Bank of Canada & 0.655 & 1.337 & 1.138 & 1.769 & 0.673 & 0.695 \\
\hline & & & & & & \\
\hline
\end{tabular}

Note: Asterisks $(*)$ denote significant differences from unity at 0.05 . 